\title{
CURRENT PROBLEMS REGARDING THE STANDING OF FOREIGN GOVERNMENTS TO SUE IN AMERICAN COURTS
}

\author{
There is no ground for the notion, that a foreign sovereign cannot' \\ sue in the courts of this country. . . . [I]t would be a monstrous \\ injustice if he could not. ${ }^{1}$
}

Although numerous rules of international law govern the sovereign activities traditionally carried on by nation states, ${ }^{2}$ different rules often apply to a nation's commercial activities. ${ }^{3}$ These activities have caused many problems, ${ }^{4}$ especially regarding standing, sovereign immunity, and acts of states.

The general United States practice has been to prohibit only unrecognized governments from suing in its courts, ${ }^{5}$ but the current world situation calls for a reappraisal of this policy since the United States is unfriendly toward several countries which it recognizes. Moreover, because many nations own or control their principal industries so that any party doing business with them must deal commercially with the governments, it has become more likely that these governments will be plaintiffs in American courts. The Castro regime is an excellent example of a recognized government that is unfriendly toward the United States; the situation there

1 Lord Redesdale in Hullet \& Co. v. King of Spain, 1 Dow \& Clarke 169, 176, 6 Eng. Rep. 488, 491 (H.L. 1828).

2 E.g., maintaining armies and navies, conducting diplomatic and consular relations, protecting the interests of nationals.

3 See Restatement, Foreign Relations Law of the United States \$ 72 (Proposed Official Draft 1962), recognizing the restrictive theory of sovereign immunity as declared in Letter From Jack B. Tate, Acting Legal Adviser to the State Department, to Acting Attorney General Philip B. Perlman, May 19, 1952, in 26 Dep'T STATE BuLl. 984 (1952) [hereinafter cited as Tate Letter]; Treaty of Friendship, Commerce and Navigation With Italy, Feb. 2, 1948, art. 24, para. 6, 63 Stat. 2255, T.I.A.S. No. 1965. Compare Berizzi Bros. Co. v. Steamship Pesaro, 271 U.S. 562 (1926), and The Schooner Exchange v. M'Faddon, 11 U.S. (7 Cranch) 116 (1812), with Ex parte Republic of Peru, 318 U.S. 578 (1943). But cf. Ioannou v. New York, 371 U.S. 30, 31-32 (1962) (Douglas, J., dissenting).

4 For a comprehensive series of articles discussing state trading and its contemporary effects, see 24 IAw \& CoNTEMP. Prob. 241-528 (1959).

In Republic of Mexico v. Hoffman, 324 U.S. 30, 40-41 (1945), Mr. Justice Frankfurter, in his concurring opinion, quoted with approval the following statement of Lord Maugham in Compania Naviera Vascongado v. The Christina, [1938] A.C. 485, 521:

Half a century ago foreign Governments very seldom embarked in trade with ordinary ships, though they not infrequently owned vessels destined for public uses, and in particular hospital vessels, supply ships and surveying or exploring vessels. These were doubtless very strong reasons for extending the privilege long possessed by ships of war to public ships of the nature mentioned; but there has been a very large development of State-owned commercial ships since the Great War ....

In the Tate Letter, the Department of State referred to "the widespread and increasing practice on the part of governments of engaging in commercial activities." 26 DEP'T STATE BULL. at 985.

5 But see text accompanying notes 48-54 infra. 
has become particularly difficult due to the severance of diplomatic relations ${ }^{6}$ between the two nations. The state of relations between the United States and $\mathrm{Cuba}^{7}$ and the nationalization of most of Cuba's industry ${ }^{8}$ present numerous problems concerning the standing of Cuba to sue in American courts.

Courts frequently fail to recognize the distinction between sovereign immunity and standing to sue. ${ }^{9}$ Historically, a foreign government was immune from all suits in American courts as a matter of international law, ${ }^{10}$ but current authorities indicate that this immunity is no longer so broad. While a foreign warship is immune from attachment, it is not clear that a vessel owned by a foreign sovereign and engaged in commercial activities is immune. In the now famous "Tate Letter" 11 of 1952, the Department of State announced that "it will hereafter be the Department's policy to follow" the practice of granting immunity only for the sovereign acts of the nation, as distinguished from its commercial acts. ${ }^{12}$ Most nations seem to agree with the State Department theory, ${ }^{13}$ but it has not been uniformly followed in American courts. ${ }^{14}$

6 The severance of diplomatic relations has caused the most confusion. John Basset Moore, in Moore, Candor and Common SENSE 30 (1930), quoted in 6 HackWORTh, Digest OF INTERNATIONAL LAW 147 (1943), stated:

While international law classes the severance of diplomatic relations among non-amicable methods of procedure, pointedly implying dissatisfaction and protest, it is equally true that the maintenance of such relations does not involve the abandonment of any claim or difference but only keeps open the channel of discussion.

Cf. Government of France v. Isbrandtsen-Moller Co., 48 F. Supp. 631 (S.D.N.Y. 1943) (severance of relations with Vichy regime); The Gul Djemal, 296 Fed. 563 (S.D.N.Y. 1921), aff'd on other grounds, 264 U.S. 90 (1924) (such governments may not file unofficial suggestions of immunity).

7 The severance of diplomatic relations occurred on January 3, 1961. 44 DEP'T State Bull. 103 (1961). For information relating to the Cuban situation see U.S. Dep't of State for Senate Comm. on Foreign Relations, 88th Cong., 1st Sess., Events in United States-Cuban Relations (Comm. Print 1963); Note, The Castro Government in American Courts: Sovereign Immunity and the Act of State Doctrine, 75 Harv. L. Rev. 1607 (1962). See generally OlIVER, The INTER-A MericaN Security System and the Cuban Crises (1962).

${ }^{8}$ See P \& E Shipping Corp. v. Banco Para el Comercio Exterior de Cuba, 307 F.2d 415, 418 (1st Cir. 1962), and authorities cited therein.

9 See text accompanying notes 54-59 infra.

10 See Berizzi Bros. Co. v. Steamship Pesaro, 271 U.S. 562, 570-74 (1926). Immunity from suit differs from immunity from execution. Compare Dexter \& Carpenter, Inc. v. Kunglig Jarnvagsstyrelsen, 43 F.2d 705 (2d Cir. 1930). "[I]n the [State] Department's view, under international law the property of a foreign sovereign is immune from execution even in a case where the foreign sovereign is not immune from suit." Letter From the Legal Adviser of the Department of State to the Attorney General, March 9, 1959, in 54 AM. J. INT'L L. 643 (1960).

11 See note 3 supra.

1226 Dep't State Bull. at 985.

13 "It is thus evident that with the possible exception of the United Kingdom little support has been found except on the part of the Soviet Union and its satellites for continued full acceptance of the absolute theory of sovereign immunity." Ibid. See Allen, The Position of Foreign States Before Natronal Courts 301 (1933).

14 See, e.g., Rich v. Naviera Vacuba, S.A., 197 F. Supp. 710 (E.D. Va.), aff'd, 295 F.2d 24 (4th Cir. 1961); United States v. Harris \& Co. Advertising, 149 So. 2d 
The standing of a foreign government to sue in American courts rests upon principles different from those governing sovereign immunity. The weight of authority overwhelmingly supports the proposition that recognized foreign nations sue in American courts not as a right, but as a privilege. ${ }^{15}$ The given reason for allowing such suits is international comity, ${ }^{16}$ a courtesy based upon good will toward the recognized government. Courts have tended to equate comity with recognition, stating that the standing of a foreign nation in American courts depends on whether it is recognized as a de jure government. ${ }^{17}$ Since there have been few cases during peacetime ${ }^{18}$ prior to the advent of the cold war which involved a recognized state with which the United States did not have amicable relations, it is only natural that the concepts of comity and recognition would become equated. But recognition of a government by the United States at some past time does not show present comity between the two nations. The question of comity is resolved by an examination of the policies and activities of the governments involved; recognition depends upon an historical act of the Executive, possibly during a period when the status of the two nations was quite different. ${ }^{19}$ It is probable that the illogical

384 (Fla. Dist. Ct. App. 1963) ; State v. Denkle, 137 So. 2d 581 (Fla. Dist. Ct. App. 1962) ; Gonzalez v. Industrial Bank (of Cuba), 33 Misc. 2d 285, 227 N.Y.S.2d 456 (Sup. Ct. 1961), aff'd, 12 N.Y.2d 33, 186 N.E.2d 410, 234 N.Y.S.2d 210 (1962).

15 "[T] he privilege . . . of suing in our courts" is "extended by comity." Guaranty Trust Co. v. United States, 304 U.S. 126, 134 (1938). "To deny him [foreign sovereign] this privilege would manifest a want of comity and friendly feeling." The Sapphire, 78 U.S. (11 Wall.) 164, 167 (1881).

18 See, e.g., Guaranty Trust Co. v. United States, supra note 15, at 134; The Sapphire, stipra note 15, at 167; Russian Socialist Federated Soviet Republic v. Cibrario, 235 N.Y. 255, 139 N.E. 259 (1923). See generally Franck, The Courts, the State Department and National Policy: A Criterion for Judicial Abdication, 44 MnNN. L. REv. 1101, 1110-11 (1960) ; Stevenson, Effect of Recognition on the Application of Private International Laze Norms, 51 CoLUM. L. REv. 710 (1951).

17 See, e.g., Guaranty Trust Co. v. United States, supra note 15, at 137; Japanese Gov't v. Commercial Cas. Ins. Co., 101 F. Supp. 243 (S.D.N.Y. 1951); Government of France v. Isbrandtsen-Moller Co., 48 F. Supp. 631 (S.D.N.Y. 1943); Union of Soviet Socialist Republics v. National City Bank, 41 F. Supp. 353 (S.D.N.Y. 1941) ; Varga v. Credit-Suisse, 5 App. Div. 2d 289, 171 N.Y.S.2d 674 (1958) ; Russian Socialist Federated Soviet Republic v. Cibrario, 235 N.Y. 255, 139 N.E. 259 (1923). There is only one reported case of an unrecognized government being allowed to sue in a United States court. See Consul of Spain v. The Conception, 6 Fed. Cas. 359 (No. 3137) (C.C.S.C. 1819) (dictum), rev'd on other grounds, 19 U.S. (6 Wheat.) 235 (1821). See also Hervey, The Legal EFFECTS of Recognition in International. LAw 112-38 (1928); Harvard Law School, Research in International Law, in 26 AM. J. INT'L L. SUPP. 503 (1932).

18 Wartime considerations are so different as to be inapplicable. See, e.g., Government of France v. Isbrandtsen-Moller Co., 48 F. Supp. 631 (S.D.N.Y. 1943); cf. United States v. Insurance Cos., 89 U.S." (22 Wall.) 99 (1874); Stumpf v. A. Schreiber Brewing Co., 242 Fed. 80 (W.D.N.Y. 1917); Plettenberg, Holthaus \& Co. v. I. J. Kalmon \& Co., 241 Fed. 605 (S. D. Ga. 1917) ; Telkes v. Hungarian Nat'1 Museum, 265 App. Div. 192, 38 N.Y.S.2d 419 (1942).

19 The decision to recognize a particular government has not been based upon United States approval of the regime since the so-called "Wilsonian policy" was discarded. The pre-Wilson practice of recognizing existent governments in control of the state with the general acquiescence of the people has been reaffirmed. Thus recognition is not in itself based upon comity. See United States Recognition Policies in 1 HACKWORTH, DIGEST OF INTERNATIONAL LAW 174-91 (1940). But see United 
equation of comity with recognition is a result of imprecise judicial language in cases permitting a recognized government to sue as a matter of existent comity. No cases have thoroughly considered the problem involved in a suit by a recognized government with which the United States does not carry on amicable relations.

Between 1917 and 1933-prior to United States recognition of the Soviet government-there were numerous cases considering the effect of nonrecognition of a foreign government. ${ }^{20}$ These cases firmly established the principle that only recognized governments can ever sue in American courts; thus, when a government is not recognized there is no need for courts to determine whether comity exists, since the allowance of standing in American courts would be inconsistent with the political policy of nonrecognition. ${ }^{21}$ Where there has been no recognition, the frequent discussions of comity by courts are superfluous-although they generally equate nonrecognition with lack of comity. ${ }^{22}$ Thus, in Russian Socialist Federated Soviet Republic v. Cibrario,23 the New York Court of Appeals held that the unrecognized Soviet government could not sue in an action to compel an accounting from an allegedly dishonest purchasing agent. The court went on to say that the plaintiff could not sue since nonrecognition barred the extension to it of comity- "reciprocal courtesy" 24 - and that comity is extended to nations exclusively by recognition. Moreover, jurisdiction depended upon the public policy of the forum as expressed by the State Department and clarified by a refusal to recognize. Numerous other authorities agree with Cibrario, ${ }^{25}$ but few consider the basis of the court's approach.

In those areas of the law where judicial action could conceivably affect the foreign relations of the United States, the Executive branch of the

States Policy of Nonrecognition of Communist China, 39 Dep'T STATE BulL. 385 (1958), stating that

basically the United States policy of not extending diplomatic recognition to the Communist regime in China proceeds from the conviction that such recognation would produce no tangible benefits to the United States or to the free world as a whole and would be of material assistance to the Chinese attempts to extend Communist domination throughout Asia.

See also 57 Am. J. INT's L. 119 (1963) (recognition of military junta in Peru).

20 For an excellent analysis of these cases see Lubman, The Unrecognized Govermment in American Courts: Upright v. Mercury Business Machines, 62 ColuM. L. REv. 275 (1962).

21 The element of recognition inherent in permitting an unrecognized government standing to sue is analogous to State Department refusal to participate in multilateral diplomatic conferences when East Germany or Communist China would also be present.

22 See authorities cited note 16 supra.

23235 N.Y. 255, 139 N.E. 259 (1923). This case evoked a storm of criticism. See, e.g., JAFFe, Judicial Aspects of Foreign Relations 149-56 (1933); Borchard, The Unrecognized Government in American Courts, 26 ANr. J. INT'L L. 261 (1932); Dickinson, The Unrecognized Government or State in English and American Law, 22 Mrch. L. Rev. 118 (1923). However, its authority has been largely unquestioned, at least until recently. See text accompanying notes 74-79 infra.

24235 N.Y. at 258, 139 N.E. at 260.

25 See authorities cited note 17 supra. 
Government, specifically the State Department, has exerted considerable influence. $^{2 B}$ Thus the "suggestion" of the State Department that a specific defendant is entitled to sovereign immunity is generally regarded as conclusive, ${ }^{27}$ and some courts will bestow such immunity in anticipation of a State Department suggestion. ${ }^{28}$ Moreover, in situations involving the "act of state" doctrine, State Department action or inaction is relevant if not binding. ${ }^{29}$ In some instances courts have attempted to read some meaning into State Department utterances, even though the State Department had no intention of affecting the resolution of a case in any way. ${ }^{30}$ The justification for such nonjudicial determination of cases is twofold: first, the Executive branch is entrusted with carrying on the foreign relations of the United States, ${ }^{31}$ and the courts are hesitant to do anything which might embarrass the Executive in this function; ${ }^{32}$ and second, it is argued that such questions are political rather than judicial, and therefore properly resolved by the political branch of the Government. ${ }^{33}$ It is clear that the

26 See, e.g., Ex parte Republic of Peru, 318 U.S. 578, 588 (1943) ("courts are required to accept and follow the executive determination that the vessel is immune"); Varga v. Credit-Suisse, 5 App. Div. 2d 289, 290, 171 N.Y.S.2d 674, 676 (1958) ("plaintiff is not a sovereign power. . . because the group ... is not recognized by the State Department"). See generally Griffin, Adjective Law and Practice in Suits Against Foreign Governments, 36 TEMP. L.Q. 1 (1962).

27 E.g., Rich v. Naviera Vacuba, S.A., 197 F. Supp. 710 (E.D. Va.), aff'd, 295 F.2d 24 (4th Cir. 1961). See generally Jessup, Has the Supreme Court Abdicated One of Its Functions?, 40 AM. J. InT'L L. 168 (1946); Lyons, The Conclusiveness of the 'Suggestions' and Certificate of the American State Department, 24 BRTT. YB. INT'L L. 116 (1947).

28 Republic of Cuba v. Arcade Bldg., Inc., 104 Ga. App. 848, 123 S.E.2d 453 (1961); cf. Ioannou v. New York, 371 U.S. 30, 31-32 (1962) (Douglas, J., dissenting). It is well-settled that, to be binding, the suggestion must come from the United States rather than the foreign government. The Gul Djemal, 264 U.S. 90 (1924); see Ex parte Muir, 254 U.S. 522, 532-33 (1921).

29 Pons v. Republic of Cuba, 294 F.2d 925, 926 (D.C. Cir. 1961), cert. denied, 368 U.S. 960 (1962); cf. Gonzalez v. Industrial Bank (of Cuba), 33 Misc. 2d 283, 284,227 N.Y.S.2d 456, 458 (Stup. Ct. 1961), aff'd, 12 N.Y.2d 3, 186 N.E.2d 410, 234 N.Y.S.2d 210 (1962): "The State Department of the United States has not filed any suggestion that sovereign immunity be considered in this action. Its failure or refusal to suggest such immunity is accorded significant weight." See also Banco Nacional de Cuba v. Sabbatino, 307 F.2d 845, 859-60 (2d Cir. 1962), cert. granted, 372 U.S. 905 (No. 403, 1962 Term, renumbered No. 16, 1963 Term); Cardozo, Judicial Deference to State Department Suggestions: Recognition of Prerogative or Abdication to Usurper?, 48 CORNELL L.Q. 461 (1963).

30 See P \& E Shipping Corp. v. Banco Para el Comercio Exterior de Cuba, 307 F.2d 415 (1st Cir. 1962), 14 Syracuse L. REv. 517 (1963). See discussion accompanying notes $41-47$ infra.

31 United States v. Curtiss-Wright Export Corp., 299 U.S. 304, 320 (1936) : "[T] international relations."

32 "Hence it is a guiding principle in determining whether a court should exercise or surrender its jurisdiction in such cases that the courts should not so act as to embarrass the executive arm in its conduct of foreign affairs." Republic of Mexico v. Hoffman, 324 U.S. 30, 35 (1945). "The guiding principle to be followed . . . is that the courts should not so act as to embarrass the executive arm in the conduct of foreign affairs." Franck, supra note 16, at 1101 . But see Mann, Judiciary and Executive in Foreigit Affairs, 29 Transact. Grot. Soc'y 143, 148-56 (1944); text accompanying notes 70-72 infra.

33 Republic of Mexico v. Hoffman, supra note 32, at 35; Guaranty Trust Co. v. United States, 304 U.S. 126, 137 (1938). See generally Dickinson, The Laze of Nations as National Law: "Political Questions," 104 U. PA. L. Rev. 451 (1956); 
political department renders decisions on recognition and other general foreign policy questions, but certain constitutional problems may arise when the Executive ventures to decide questions determinative of a particular legal action. ${ }^{34}$

\section{Contemporary Judicial Action}

In Republic of Cuba v. Mayan Lines, S.A., ${ }^{35}$ the Republic of Cuba sued to annul a money judgment obtained by defendant Mayan Lines in a prior action. A lower state court upheld defendant's contention that Cuba could not sue because it lacked procedural capacity and held that, as it was a nation with which the United States does not carry on diplomatic relations, proper certification of a representative to bring the suit on Cuba's behalf was impossible. ${ }^{36}$ The Louisiana Court of Appeals reversed and held that any recognized "foreign sovereign" could bring an action in American courts in its own name. The court stated that the error of the trial court "lies in the failure to distinguish between continuing diplomatic recognition of sovereignty and the maintenance of continuing diplomatic relations between sovereigns." 37

According to the court, recognition continues until "expressly withdrawn . . . by the appropriate political department" of the United States Government. ${ }^{38}$ The breach of diplomatic relations with Cuba was of no moment to the court. Although the general rule has been that courts will equate recognition with comity and comity with standing to sue, the court eliminated all consideration of whether comity existed between the two governments. While this approach eliminates the fictitious aspects of the recognition-comity equation, it ignores the fact that standing to sue is a privilege generally granted to foreign governments and not a legal right accompanying recognition. ${ }^{39}$ Such a legalistic approach oversimplifies the problems involved in order to obtain a uniform result. ${ }^{40}$

Jaffe, Standing To Secure Public Review: Public Actions, 74 Harv. L. REv. 1265, 1305 (1961) ; Wechsler, Toward Neutral Principles of Constitutional Laze, 73 Harv.

L. Rev. 1 (1959). See text accompanying notes 70-72 infra.

34 See text accompanying notes 80-83 infra.

35145 So. 2d 679 (La. Ct. App. 1962).

36 Id. at $681-82$.

37 Id. at 683 .

38 Ibid.

39 See Calderone v. Naviera Vacuba S/A, No. 27689, $2 d$ Cir., Nov. 20, 1963; Compania Ron Bacardi, S.A. v. Bank of Nova Scotia, 193 F. Supp. 814, 815 (S.D.N.Y. 1961). The courts reached the same result as the court in Mayan Lines regarding a Cuban corporation. In the latter case, the court stated: "With respect to the status and acts of the Cuban government, United States executive expressions at this time leave little doubt that the national policy to be followed by American courts requires that the standing of this plaintiff be recognized."

40 For the proposition that severance of diplomatic relations does not alter the sovereign's standing in United States courts, the court cited Corpus Juris Secundum and dictum in Lehigh Valley R.R. v. State of Russia, 21 F.2d 396, 401 (2d Cir. 1927). 145 So. 2d at 683 . A similar approach was taken in Japanese Government v. Commercial Cas. Ins. Co., 101 F. Supp. 243 (S.D.N.Y. 1951), which held that Japan could sue in United States courts even though the claim had arisen in 1949 while a state of war still existed and therefore during a period when the United States did not carry on diplomatic relations with Japan. The State Department seems to agree with this position. 57 AM. J. INT'L L. 409-10 (1963). 
In $P$ \& E Shipping Corp. v. Banco Para el Comercio Exterior de $C u b a,{ }^{41}$ defendant $\mathrm{P} \& \mathrm{E}$ Shipping Corporation had refused to deliver a cargo of beans and potatoes to Cuba following the United States embargo on exports to that country. The nationalized bank which carried on the foreign commerce of the Cuban government sued to recover damages for breach of the maritime contract. Relying upon the severance of diplomatic relations, the court of appeals reversed a judgment for the plaintiff and remanded the case for the district court to ascertain from the State Department the status of the Republic of Cuba in American courts, the plaintiff bank's relationship to the Cuban government, and the status of United States plaintiffs in Cuban courts. ${ }^{42}$

This decision relied primarily upon a statement in National City Bank v. Republic of China ${ }^{43}$ that "the status of the Republic of China in our courts is a matter for the determination of the Executive and is outside the competence of this Court." 44 In that case, the Supreme Court allowed a setoff against the Republic of China, overruling a plea of sovereign immunity. In reaching that decision, the Court was cognizant of State Department policy regarding the sovereign immunity issue at hand and was not referring to the standing of the plaintiff. Yet the court in $P \& E$ took the statement to indicate a desire on the part of the Supreme Court to allow all questions touching upon the "status" of a foreign government in American courts to be decided by the State Department.

The underlying rationale of the $P \& E$ decision was the court's fear that by reaching a decision without State Department guidance it would embarrass the Executive branch in its conduct of the foreign relations of the United States. But, regardless of whether a breach of contract is likely to turn into a serious international incident, any fear of prejudice to this country's foreign relations is unwarranted, since at worst the Executive could disclaim responsibility for what was an inapt decision by the court and remedy the situation diplomatically. ${ }^{45}$ The most probable way to embarrass the Executive would be to force it to make a decision it did not want to make which could have some binding effect upon it in the future; this the court did by requesting advice which the State Department had shown no desire to give. ${ }^{46}$ Unlike a question of sovereign immunity, which may result in attachment of sovereign property, the question of standing is properly decided by a court. ${ }^{47}$

41307 F.2d 415 (1st Cir. 1962), 4 Harv. Int'L L. Club J. 114 (1962), 14 SyraCUSE L. REv. 517 (1963).

42307 F.2d at 418.

43348 U.S. 356 (1955).

44 Id. at 358.

45 See Mann, supra note 32, at 153.

46 In the Tate Letter, the State Department stated that "the widespread and increasing practice on the part of governments of engaging in commercial activities makes necessary a practice which will enable persons doing business with them to have their rights determined in the courts." 26 DEP'T STATE BuLL. at 985; cf. 56 AM. J. INT'L L. 526-31 (1962) ; Griffin, supra note 26, at 3-4.

47 In Russian Reinsurance Co. v. Stoddard, 240 N.Y. 149, 158, 147 N.E. 703, 705 (1925), the court stated that the State Department "cannot determine how far the private rights and obligations of individuals are affected by acts of a body . . . with 
Dade Drydock Corp. v. The $M / T$ Mar Caribe ${ }^{48}$ was an admiralty action in which the Agricultural and Industrial Development Bank of Cuba intervened as claimant of the M/T Mar Caribe, alleging that as a credit institution and mortgagee of the vessel it was entitled to possession thereof. The vessel was being used for the commercial purposes of the Republic of Cuba at the time of attachment. The court held that, as an arm of the Cuban government, the bank could not intervene or sue as claimant.49 A plea of sovereign immunity had been refused because of the breach of diplomatic relations and the failure of the State Department to file a suggestion of immunity. ${ }^{\text {so }}$

The basis of the decision was the court's conclusion that the Republic of Cuba was not recognized by the United States and therefore neither it nor anyone acting on its behalf could bring suit. The court was obviously incorrect in its concept of recognition: it stated that the break in diplomatic relations "resulted in withdrawal of diplomatic recognition of the Republic of Cuba." 51 The court found no authority to justify equating severance of diplomatic relations with withdrawal of recognition; in fact, there are large differences between the two. ${ }^{52}$

The court may have reached a desirable result, however, since the underlying basis of the decision seems to be the obvious lack of comity between the two governments. The court did not treat the comity concept at all, but it is apparent that the existence of strained relations was largely responsible for the decision. ${ }^{53}$ While the court was plainly unaware of the legal issues involved in regard to comity, recognition, and the breach of diplomatic relations, its result may be preferable to those reached by more

which our Government will have no dealings." See also The Pacquete Habana, 175 U.S. 677 (1900); Sprout, Theories as to the Applicability of International Law in the Federal Courts of the United States, 26 Am. J. INT' L. 280, 294 (1932), in which the author states, "the court may draw upon the subject-matter of international law because that law forms part of the municipal common law of the land."

48199 F. Supp. 871 (S.D. Tex. 1961).

49 The court did not hold that the action abated or was subject to dismissal. It simply held that the action is suspended during the period of severed diplomatic relations between the United States and Cuba. Id. at 874.

50 The court stated that the "plea of sovereign immunity is not available on behalf of the Republic of Cuba," citing The Gul Djemal, 296 Fed. 563 (S.D.N.Y. 1921), aff'd on other grounds, 264 U.S. 90 (1924), which merely held that Turkey, with which the United States did not then carry on diplomatic relations, could not file an unofficial suggestion of immunity. $199 \mathrm{~F}$. Supp. at 874.

51 Ibid.

52 The distinction was recognized in Republic of Cuba v. Mayan Lines, S.A., 145 So. 2d 679 (La. Ct. App. 1962). See text at note 37 supra; Japanese Gov't v. Commercial Cas. Ins. Co., 101 F. Supp. 243 (S.D.N.Y. 1951). Harvard Law School, Research in International Law, supra note 17, at 504, also stated that different conclusions should be drawn from lack of recognition and severance of diplomatic relations. In BRIGGS, THE LAW of NATroNs 132 (1952), the author states: "Severance of diplomatic relations is not necessarily a withdrawal of recognition."

53 Compare this result with the following statement from The Gul Djemal, 296 Fed. 563, 564 (S.D.N.Y. 1920), aff'd on other grounds, 264 U.S. 90 (1924): "If a breach of such relations means simply that thereafter a government may by indirection obtain and secure for itself the same rights and privileges that would, but for the breach, be directly accorded it, the severance of relations is an idle ceremony, so far as comity between nations is concerned." 
extensive considerations of the issues. ${ }^{54}$ Certainly, the policy questions present in a determination of comity are more related to a current severance of diplomatic relations than to an early, and perhaps premature, recognition.

\section{Confusion Between Sovereign Immunity and Standing To Sue}

Several cases which were decided on principles relating to a nation's standing to sue could have been decided on other theories. Both Mayan Lines, a civil action resulting in a money judgment, and Dade, an admiralty attachment proceeding, were first presented as sovereign immunity questions with Cuba as a party defendant. ${ }^{55}$ Full determinations of the rights and liabilities of the parties should have been reached in these earlier suits. Even though it is arguable that Cuba was not entitled to sovereign immunity, ${ }^{56}$ this should have been the basis for the decisions rather than the standing of the unfriendly sovereign. Such manipulation of the issues should not be allowed, as knowledgeable parties may be able to succeed as defendants when success as a plaintiff would not have been possible. And by such maneuvering a party may take advantage of a situation where the sovereign is unable to protect its property through legal means.

Since sovereign immunity turns on considerations different from standing, the courts should be on guard against parties who wish to confuse the two issues. For example, if an officer of a local 'government attaches property belonging to a foreign sovereign and the sovereign brings suit to invalidate the attachment on the ground of sovereign immunity, the court should examine the validity of the attachment to determine whether it is valid under the applicable sovereign immunity doctrine. A simple refusal to allow the sovereign to bring suit would in effect give what may be an illegal act the stamp of judicial approval, rendering sovereign immunity a death blow as a viable and enforceable doctrine. ${ }^{57}$ Since the Executive cannot be expected to remain aware of all such actions, especially when diplomatic relations are not conducted with the nation in question, ${ }^{58}$

54 In Plasticos Industriales Extrusos, S.A. v. Bank of Nova Scotia, 38 Misc. $2 d$ 9, 237 N.Y.S.2d 802 (Sup. Ct.), aff'd mem., 240 N.Y.S.2d 934 (App. Div. 1963), the court, considering a motion to dismiss on the ground of fortun non conveniens in order to permit Cuban claimants to intervene in another forum, stated: "There is no showing that any alleged claimants may sue in our courts." Id. at 10, 237 N.Y.S.2d at 804.

55 See text accompanying notes 36 and 50 sipra.

56 See Drachsler, Some Observations on the Current Status of the Tate Letter, 54 AM. J. INT'L I. 790 (1960); authorities cited note 3 supra and accompanying text.

57 Compare the denial of standing in this situation with withdrawal of state and federal court jurisdiction which deprives parties of substantive rights, as was argued in Battaglia v. General Motors Corp., 169 F.2d 254, 257 (2d Cir.), cert. denied, 335 U.S. 887 (1948). For a development of this analogous problem see HART \& WECHSLER, The Federal Courts and the Federal System 292-302 (1953).

58 Severance of diplomatic relations makes it difficult to carry on the normal communications between governments. For example, the ostensible reason given by President Eisenhower for the break was the requirement by Cuba that the United States reduce its staff to eleven officials, which would "render impossible the conduct of normal diplomatic relations." 44 DEP'T STATE BuLL. 103-04 (1961). During the period of the severance, Cuba must utilize the Czechoslovakian embassy as intermediary in order to make its grievances known to the United States Government. U.S. Def't of State for Senate Comm. on Foretgn Relations, 88th Cong., Ist Sess., Events in United States-Cuban Relations 19 (Comm. Print 1963). 
sovereign property must be protected by other means. Perhaps the Executive should be informed by the nation in question through the consular office of the representing government-Czechoslovakia in the instance of $\mathrm{Cuba}-, 59$ but there is little assurance that such a scheme would succeed, and, in certain situations, the task must fall upon the courts. To do otherwise would be to facilitate confiscation of sovereign property.

It is clear that two types of confusion are likely to recur: a standing problem being treated as a sovereign immunity case, and a sovereign immunity issue being treated as a standing problem. Although there may be little danger respecting the latter type of confusion when the Tate Letter suggests that there is no sovereign immunity, courts should face this issue. But when there is no immunity, or when a standing case is confused with a sovereign immunity problem, solutions will result only from a willingness on the part of courts to analyze carefully the elements of the particular case.

Several cases involve no sovereign immunity question but are different from ordinary litigation only in the sovereign nature of the plaintiff. The $P \mathcal{E} E$ case is an example of an action in which the primary legal issue is that of the standing of the plaintiff. But $P \& E$ was decided by reference to a sovereign immunity precedent, ${ }^{60}$ in much the same way as Dade and Mayan Lines, which were sovereign immunity cases, were viewed as standing questions. Since state trading is currently of great importance, commerce in general will be hampered by confused legal treatment. Moreover, it appears clear that the problems are amenable to solution if courts and counsel will look at them realistically rather than legalistically.

\section{Possible Solutions}

\section{A. All Recognized Foreign Governments Have Standing}

The virtues of the approach utilized by the Mayan Lines court are its certainty, its uniform result, and its amenability to judicial determination. The diversity of results in standing cases indicates the need for a uniform standard making it possible for a litigant to predict his rights and liabilities, especially whether he is suable or can sue. The results of the Mayan Lines, $D a d e$, and $P \& E$ cases, in which no agreement whatsoever was shown, demonstrate this need, and, when those cases are contrasted with analogous cases not even raising the issue, ${ }^{61}$ it becomes obvious that the system has not adequately coped with these peculiarly modern problems. As state

59 See Flota Maritima Browning de Cuba, S.A. v. Motor Vessel Ciudad de la Habana, 218 F. Supp. 938 (D. Md. 1963).

60 The court cited National City Bank v. Republic of China, 348 U.S. 356 (1955), as controlling the "status" of the Republic of Cuba in United States courts. See text accompanying note 43 supra.

61 Such judicial decisions were rendered in at least two appellate cases after relations were severed. See Banco Nacional de Cuba v. Sabbatino, 307 F.2d 845 (2d Cir. 1962), cert. granted, 372 U.S. 907 (No. 403, 1962 Term, renumbered No. 16, 1963 Term) ; Pons v. Republic of Cuba, 294 F.2d 925 (D.C. Cir. 1961), cert. denied, 368 U.S. 960 (1962). 
trading becomes the rule rather than the exception, the problems can only become more acute.

The judicial rather than Executive determination of the Mayan Lines approach also militates in its favor. Aside from the Executive's preference for judicial determination, ${ }^{62}$ and the elimination of the Executive from a judicial aspect of foreign relations, restricting these issues to the judiciary would allow the courts to develop uniform standards for the related problems involved. This increased competence is not possible if the courts are willing to defer to the Executive upon slight or no evidence of possible foreign policy repercussions. Unsolicited judicial abdication, as in $P \& E$, may cause some of the very problems it attempts to avoid.

But under the Mayan Lines theory, the concept of international comity -properly the basis for the standing of a foreign sovereign in American courts ${ }^{63}$-is an utter fiction. Since all recognized governments could bring suit in American courts, comity would have the same meaning as recognition, an unusual equation. Mr. Justice Bradley's statement in The Sapphire "64 that to deny a foreign sovereign the right to sue "would manifest a want of comity and friendly feeling" ${ }^{65}$ is undoubtedly correct, but where a lack of "comity and friendly feeling" has already been manifested it seems pointless to allow the sovereign to sue. The fallacy in the Mayan Lines approach lies in the assumption that past recognition indicates present comity. Furthermore, this assumption cannot be overriden by any action short of withdrawal of recognition.

It is doubtful that recognition may ever be withdrawn, except when one government is replaced by another and the new government is recognized in its place. ${ }^{66}$ Since "instances of express withdrawal of recognition are rare and withdrawal of recognition unaccompanied by the recognition of a new regime practically nonexistent," ${ }^{67}$ it would not be possible under existing international practice to prevent the foreign government from bringing suit in the courts of the recognizant. It is very doubtful if the merits of the Mayan Lines approach justify such a straitjacketing of both the courts and the Executive.

Even if it is assumed that international practice permits the Executive to withdraw recognition of a particular government because of a conflict in national policies, this drastic action with all its collateral effects may not

62 See note 46 supra.

63 See notes 15-16 supra and accompanying text.

6478 U.S. (11 Wall.) 164 (1871).

65 Id. at 167 (dictum). In this case the Supreme Court upheld the right of the French Emperor to bring suit in American courts.

68 "Recognition is unconditional and irrevocable." Inter-American Convention on Rights and Duties of States, Dec. 26, 1933, art. VI, 49 Stat. 3097, T.S. No. 3802. Restatenent, Foreign Relations LaW of the United States \$99 (Proposed Official Draft 1962), states that recognition may be withdrawn "only if (1) the recognized government does not exercise the functions of government . . . ; or (2) the recognizing state has reserved the power to withdraw the recognition; or (3) the withdrawal is effected by recognition of a successor government."

67 BRIGGS, op. cit. supra note 52, at 132 . 
be justified by what could be an inconsequential gain realized by denying the unfriendly government access to American courts. The United States would be faced with two alternatives: withdraw recognition or allow the government to sue in American courts. This lack of alternatives could impair the resolution of many already difficult problems. ${ }^{68}$

\section{B. Ad Hoc Executive Determinations}

The approach of the $P \& E$ court gives the Executive flexibility in solving problems as they occur, without being bound by prior action on the part of the judiciary or the Executive. Since the effects of a particular determination will probably vary from case to case, it is arguable that any other method would unduly restrict the conduct of United States foreign relations. But concomitant with this approach is the danger of judicial deferral in favor of the Executive, with the Executive exercising a right of decision appropriately exercised only by the courts. ${ }^{69}$ Moreover, the uniform standard attainable via the Mayan Lines approach cannot be achieved unless the State Department chooses to be bound by its past decisions, which is not only unlikely but also undesirable if needed flexibility is to be assured. The mere concept of the $a d$ hoc determination is alien to the common-law tradition, especially in cases that lend themselves to judicial determination, and it is doubtful if the exigencies of the situation require nonjudicial resolution. Furthermore, when the standing of foreign sovereigns is in issue, the State Department has shown no desire to intervene ${ }^{70}$-evidence of the Executive's disagreement with the approach of the $P \& E$ court.

The ostensible reason for judicial deference to the Executive is fear of embarrassing the Executive in its conduct of foreign relations. But this fear, often resorted to as a rationale in cases concerning sovereign immunity or acts of state where the likelihood of embarrassment is greater than in standing-to-sue cases, often seems to be of makeweight proportions. Obviously, certain decisions by courts result in conflicts with Executive policies. But these situations are probably more rare than is imagined, and the damage inflicted may not be as serious as certain judges seem to feel. Sir Wilfred Greene summarized these contrary arguments when he stated:

I do not myself find the fear of the embarrassment of the Executive a very attractive basis upon which to build a rule of English.law, and, in the present case, the argument presents a certain air of unreality . . . . [I]t would appear that the Executive is in need of being protected against itself. ${ }^{71}$

68 For a discussion of the policy of recognition, see note 19 supra.

69 See Jessup, supra note 27.

70 See authorities cited note 46 supra.

71 Kawasaki Kisen Kabushiki Kaisha v. Bantham S.S. Co., [1939] 2 K.B. 544, 552 (dictum). 
Certainly, the avoidance of embarrassment must be balanced against the evil resulting from refusals by courts to ascertain and declare the law. In the $P \& E$ case, for example, it is unlikely that there would have been any resultant Executive embarrassment, however the court might have decided the issues. Even if the Executive had a firm policy against allowing Cuba to recover damages in American courts, allowing Cuba to recover for breach of contract to deliver beans and potatoes would cause little direct harm to the conduct of United States foreign relations. Similarly, a nonallowance of suit when the Executive desired that suits be allowed would be minor in its consequences; at worst, the Executive could award the suing nation its damages by diplomatic negotiations in return for an assignment of a claim against the United States defendant. ${ }^{72}$ Of course, in particularly precarious situations the courts would still have to look to the Executive for statements of policy, but these occasions are extremely rare and thus should not serve as a foundation for general United States policy.

While the practice of applying to the Executive for guidance is a useful device clarifying potentially difficult decisions for the courts, the possible embarrassment that might result from an improper decision by a court must be weighed against the embarrassment caused by forcing the Executive to make a decision it neither is prepared to make nor desires to give. Even when a policy is formulated, the Executive may not wish to disclose these views or intentions for what may be very crucial foreign policy reasons. An incorrect judicial decision, however undesirable, may be preferable to an Executive declaration, since the judicial decision does not commit the Executive but leaves it free to disclaim adherence to the incorrect views. ${ }^{73}$

\section{Application of Public Policy}

In Cibrario, ${ }^{74}$ the Soviet government was barred from bringing suit in the United States for misappropriation of its funds. The basis for the refusal was the nonrecognition of the Soviet government which led the court to conclude that the United States would not extend comity to the Soviet Union. In arriving at its conclusion, the court stated:

${ }^{72}$ Cf. United States v. Pink, 315 U.S. 203 (1942); Upright v. Mercury Business Machs. Co., 13 App. Div. 2d 36, 39, 213 N.Y.S.2d 417, 421 (1961). In Upright, the court stated that "the lack of jural status for such government or its creature corporation is not determinative of whether transactions with it will be denied enforcement in American courts, so long as [that] . . . government is not the suitor."

73 See Mann, Judiciary and Executive in Foreign Affairs, 29 Transact. Grot. Soc'y 143, 148-56 (1944).

While it is certain that the practice of applying to the Executive is in many respects a useful device, it should not be overlooked that it may sometimes be more embarrassing to the Executive than an independent decision of the Courts which does not commit the Government and may be, therefore, often less prejudicial than Judges are inclined to think. . . [T] [Te danger of the existing practice lies in compelling an unwilling or temporising Executive to disclose its views or intentions.

Id. at 153 .

74 Russian Socialist Federated Soviet Republic v. Cibrario, 235 N.Y. 255, 139 N.E. 259 (1923). 
Undisturbed the rule of comity is our only guide. This rule is always subject, however, to one consideration. There may be no yielding, if to yield is inconsistent with our public policy. . . . [J] urisdiction depends upon the law of the forum, and this law in turn depends upon the public policy disclosed by the acts and declarations of the political departments of the government. ${ }^{75}$

Under this approach, the courts determine the application of the public policy to the particular case at hand.

While a rule grounded upon the public policy of the United States would be helpful in determining standing-to-sue questions, it is not altogether clear that such a rule could be successfully implemented or applied. In cases like Cibrario, where the plaintiff government was not recognized by the United States, the public policy was more apparent than in most current situations. Moreover, the Cibrario approach has been the subject of frequent criticism ${ }^{76}$ and has been limited in its application by the recent decision in Upright v. Mercury Business Machs. Co. ${ }^{77}$ which held that it is not contrary to the public policy of the United States to allow an assignee of the unrecognized German Democratic Republic to bring suit in the United States.

The practical considerations inherent in a scheme whereby the courts look to the State Department for determinations of policy point out the difficulty of obtaining a uniform result, as there is no assurance that different courts will draw the same inferences from a given statement of policy. Therefore, there would be a probability of ad hoc decisions by the courtslittle improvement over the $a d$ hoc State Department determinations likely to result from the $P \& E$ approach. Although it is now clear that an unrecognized government cannot bring suit in American courts, ${ }^{78}$ there would be no restriction to prevent courts from overturning their holdings in an unbroken line of cases by deciding that a particular government, recognized or not, could sue because the suit is in accord with the policy of the forum. ${ }^{79}$ It is not unlikely that courts would frustrate the foreign policy objectives of the Executive by making clearly inaccurate policy determinations, misinterpreting a decision of the political branch. To avoid this possibility, the State Department would be forced to make declarations of policy to cover every conceivable instance, declarations the State Department might not wish to make.

75 Id. at 259-60, 139 N.E. at 260-61 (dictum).

${ }^{76}$ See Lubman, The Unrecognized Government in American Courts: Upright $v$. Mercury Business Machines, 62 CoLvM. L. REv. 275, 298-99 (1962); authorities cited note 23 supra. 299-310.

7713 App. Div. 2d 36, 213 N.Y.S.2d 417 (1961) ; see Lubman, supra note 76, at

78 See authorities cited note 17 supra.

79 "So, too, only limited effect is given to the fact that the political arm has not recognized a foreign government." Upright $v$. Mercury Business Machs. Co., 13 App. Div. 2d 36, 39, 213 N.Y.S.2d 417, 420 (1961) (dictum). 


\section{Conclusion: Utilizing Past Political Action as a Guide to International Comity}

The current cold war situation, when all-out war cannot be utilized as a weapon of national policy, calls for some means short of withdrawal of recognition whereby the Executive can deny the favor of standing to unfriendly governments in American courts. There is an anomaly in not allowing the People's Republic of China to sue and allowing the Cuban government this privilege, wholly because at some time the Executive chose to recognize one established regime and not the other. The basis of these Executive decisions was undoubtedly different from the considerations regarding standing to sue. Furthermore, in the present Cuban crisis, the political policy is clear; Congress and the Executive have, through particular acts, declared open economic warfare upon Cuba. ${ }^{80}$ Since Cuban standing is ultimately dependent upon political action (existent comity), the courts should further this policy rather than detract from it. But courts should not allow the Executive to make determinations that are dispositive of a case, once it has reached the courts; while cognizant of foreign affairs policy, courts must still fulfill their function of deciding individual cases. In addition to the reasons already given in favor of judicial determination of such cases, the policy behind the constitutional requirement of separation of powers ${ }^{81}$ and the grant of exclusive jurisdiction to the courts to decide cases and controversies is at odds with nonjudicial determination. International law is applied by the judiciary, ${ }^{82}$ and so long as jurisdiction has been properly invoked, courts have a duty to decide all judicial questions, ${ }^{83}$ including the standing of the parties. While a court may rely on prior Executive statements in much the same way as legislative history aids a

80 On July 3, 1960, Congress gave the President the authority to reduce the import quota on Cuban sugar; on October 19, 1960, the United States prohibited exports to Cuba, with certain minor exceptions; on September 7, 1961, the United States prohibited assistance to any country which assists Cuba, unless the President should determine otherwise; on February 3,1962, the United States proclaimed a complete embargo on trade with Cuba, except for exports of food and medicines; on March 24, 1962, the United States prohibited imports of merchandise made or derived in whole or in part of products of Cuban origin. U.S. Dep'T of State for Senate Comm. on Foretgn Relatrons, 88th Cong., 1st Sess., Events in United States-Cuban ReLations 14, 18, 20, 21 (Comm. Print 1963). On July 8, 1963, at the request of the Secretary of State, the Treasury Department instituted orders that (1) block all assets in the United States of Cuba or of persons in Cuba, (2) prohibit persons subject to the jurisdiction of the United States from engaging in unlicensed transfer of United States dollars to or from Cuba, and (3) prohibit all other unlicensed transactions with Cuba or Cuban nationals or transactions involving property in which there is a Cuban interest. 49 DEP'T STate Bull. 160 (1963), referring to Dep't State Press Release No. 360, July 8, 1963.

81 Cf. Tenney v. Brandhove, 341 U.S. 367, 373-75 (1951). Perhaps some American decisions to the contrary are results of reliance upon British precedents, cases from a country which does not require separation of powers.

82 "The Judicial Power shall extend . . to Controversies . . between a State, or the Citizens thereof, and foreign States, Citizens or Subjects." U.S. Const. art. III, \$2. See The Pacquete Habana, 175 U.S. 677 (1900); Sprout, supra note 47 , at 294 .

${ }^{83}$ Cf. Baker v. Carr, 369 U.S. 186, 211-15 (1962) ; Marbury v. Madison, 5 U.S. (1 Cranch.) 137 (1803). 
court to interpret a statute, an independent judiciary must refrain from abdicating its case-deciding function to the Executive.

Although there is no question that the Dade court was incorrect in equating breach of diplomatic relations with withdrawal of recognition, for the purposes of that case the equation might have been proper. The conflicts which caused the severance of diplomatic relations are analogous to the reasons for refusing to recognize what is obviously a de facto government in the case of Communist China. Therefore, if lack of recognition indicates a lack of comity, a severance of diplomatic relations indicates this same condition, and the same result should ensue.

It is arguable that this result may hamper the foreign relations of the United States because in some situations the State Department may deem it expeditious to allow a particular government to sue.84 However, this objection is equally appropriate to the blanket refusal to allow unrecognized governments to sue, and no serious consequences have resulted from that denial. The arguments in favor of close Executive supervision of individual legal actions even remotely affecting international relations may be valid in the contexts in which they generally appear ${ }^{85}$ _act of state and sovereign immunity-but there is no reason to carry the rationale outside these spheres of application. The experience in reference to disallowance of suit by unrecognized governments indicates that the same problems do not arise, and the results should not differ in other instances where comity is nonexistent.

Consistent with the constitutional requirement of separation of powers, this approach retains the aspect of judicial determination of the Mayan Lines approach without its accompanying unrealism. The Executive branch would not intrude into judicial matters, as in $P \& E$, nor would it be forced to disclose views upon which it may prefer to remain silent. When the Executive might wish to negate a judicial result in the name of United States foreign relations, the avenues of diplomatic settlement would remain open, and, if the problems are particularly acute, the diplomatic solution would probably be more effective. ${ }^{86}$

\section{J. Gordon Hansen}

84 See Brief for the United States as Amicus Curiae, pp. 47-48, Banco Nacional de Cuba v. Sabbatino, cert. granted, 372 U.S. 905 (No. 403, 1962 Term, renumbered No. 16, 1963 Term).

85 See generally Cardozo, Iudicial Deference to State Department Suggestions: Recognition of Prerogative or Abdication to Usurper?, 48 CORNELL L.Q. 461 (1963); Franck, The Courts, the State Department and National Policy: $A$ Criterion for Judicial Abdication, 44 MrNN. L. Rev. 1101 (1960).

86 The power to enter into such agreements is part of the general constitutional grant to the Executive to carry on the foreign relations. See United States v. CurtissWright Export Corp., 299 U.S. 304 (1936). Such diplomatic solutions would fall into the general category of Executive agreements. See generally BISHOP, INTERNATIONAL LAW 94-105 (2d ed. 1962). 